\title{
The rare zoarcid fish Ophthalmolycus macrops (Günther, 1880) (Osteichthyes: Perciformes: Zoarcidae) in Chile
}

\author{
El raro pez zoárcido Ophthalmolycus macrops (Günther, 1880) \\ (Osteichthyes: Perciformes: Zoarcidae) en Chile \\ Germán Pequeño ${ }^{1}$ and Sylvia Sáez ${ }^{1}$ \\ ${ }^{1}$ Instituto de Zoología “Ernst F. Kilian”. Universidad Austral de Chile \\ Casilla 567, Valdivia, Chile \\ gpequeno@uach.cl
}

\begin{abstract}
Resumen. El pez zoárcido Ophthalmolycus macrops ha sido conocido hasta el momento solamente por siete ejemplares en aguas chilenas, prácticamente todos capturados en la zona de la boca occidental del estrecho de Magallanes y una zona al norte de la misma y cercana a ella. Exploraciones recientes han conseguido cinco nuevos ejemplares en la zona norte de los fiordos chilenos y también, al sur del estrecho de Magallanes. Estos nuevos ejemplares han permitido conocer rasgos morfológicos adicionales a los previamente descritos y
\end{abstract}

también ampliar los límites de distribución geográfica con dos nuevos registros, al norte y al sur, los que la señalan siempre como una especie endémica de los fiordos de Chile. La baja frecuencia de aparición de esta especie podría deberse a la escasa exploración ictiológica de la región. En todo caso, los escasos hallazgos la muestran como una especie rara.

Palabras clave: Pisces, Pacífico suroriental, Ophthalmolycus, ictiogeografía

\section{Introduction}

Fishes of the family Zoarcidae from the extreme south of South America, particularly in Chilean waters, have been little studied as a group (Regan 1913, Norman 1937, Gosztonyi 1977). Although a series of contributions on this family have been published in recent years, only very recently new specimens of Ophthalmolycus macrops (Günther, 1880) have been collected. This species represents one of the rarest of the family, and thus represents one of the least known zoarcids in the region (Pequeño \& Lamilla 1996). Until the study by Norman (1937), the species was known only from the holotype, caught at Puerto Bueno $\left(50^{\circ}\right.$ 56 'S), in the northern part of Chile's Magellan and Chilean Antarctic Region. Later its existence was reported near the western entrance of the Magellan Straits $\left(52^{\circ} 51^{\prime} \mathrm{S}\right)$, based on six specimens collected there (Anderson \& Gosztonyi 1991) (Fig. 1). Thus all previous studies were based on only seven specimens, deposited in different European collections. The CIMAR-Fjord cruises, sponsored by the Comité Oceanográfico Nacional (CONA), made new collections of fishes in southern Chile in the Aysen Region, which is one of the ichthyologically least well explored regions in the world. This area is rich in fjords, channels, and islands, and may allow the establishment of diverse faunas at various depths. Fishes collected on these cruises have included a few examples of zoarcids. A previous collection including these fishes from the region was made by the $\mathrm{R} / \mathrm{V}$ "Victor Hensen" (Germany) in 1994 in the extreme southern continental part of Chile (Fig. 1).

Many species of bottom fishes, typically zoarcids among them are interesting from the standpoint of ichthyogeography. In the case of $O$. macrops, collections of which have been restricted to the most southerly channels of Chile, we have no knowledge of the intraspecific morphological variation which may occur in cases where new individuals may be collected at latitudes distant (north and south) from those of the presently known records. Since so few individuals have been available for examination, any new collections of this species are undoubtedly of great value in ichthyogeography. The recovery of samples of $O$. macrops more than $600 \mathrm{~km}$ north, as well as $200 \mathrm{~km}$ south of previous records allows new and valuable contributions in this field. 


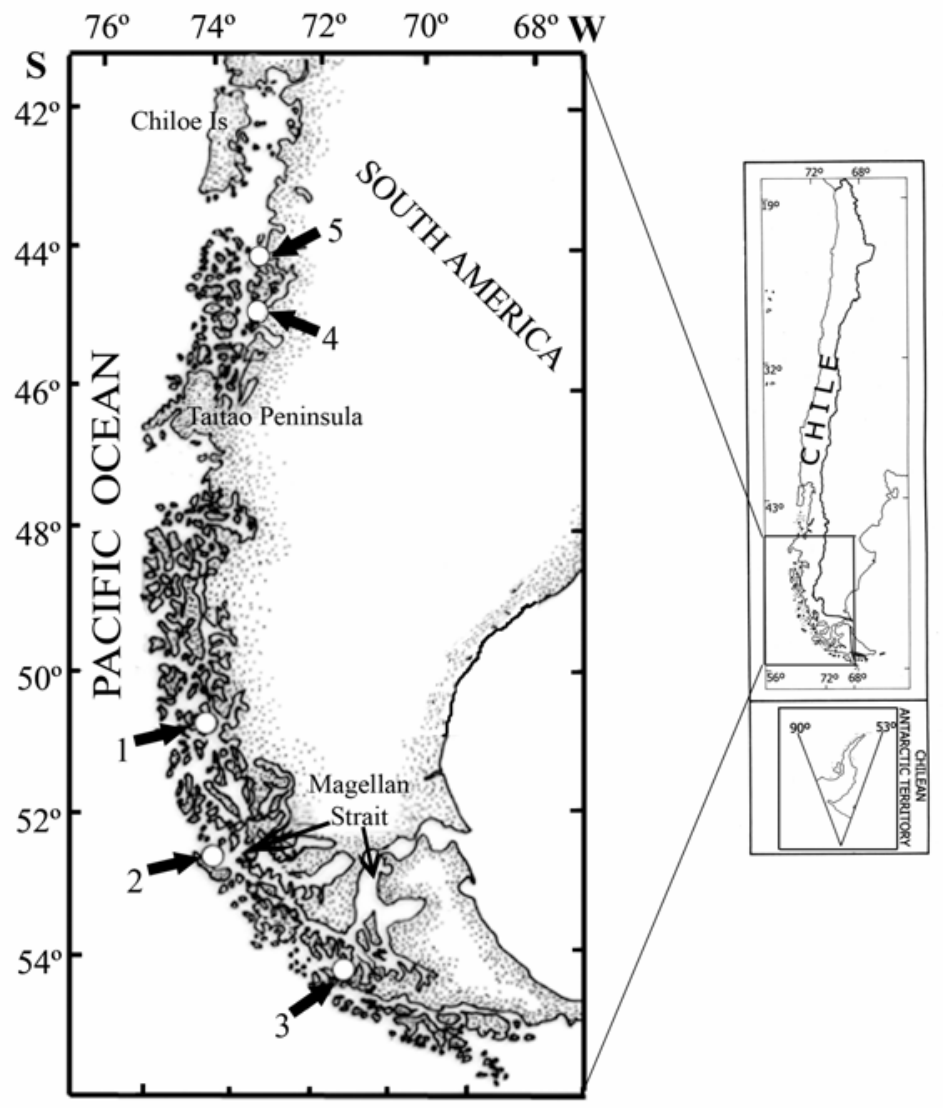

Figure 1

Sampling locations for Ophthalmolycus macrops, chronologically listed:

1, Puerto Bueno (HMS “CHALLENGER”, 1876); 2, western mouth of the Magellan Strait (“Víctor Hensen”, 1966)

3, south of the Magellan Strait (R/V “Victor Hensen”, 1994); 4, mouth of Puyuhuapi channel (AGOR “Vidal Gormaz”, 2001), and 5, off Toto Island (AGOR “Vidal Gormaz”, 2001).

Lugares de muestreo para Ophthalmolycus macrops, ordenados cronológicamente: 1, Puerto Bueno (HMS “CHALLENGER”, 1876); 2, boca oeste del estrecho de Magallanes (R/V "Víctor Hensen", 1966); 3, al sur del estrecho de Magallanes (R/V "Víctor Hensen", 1994); 4, boca del canal Puyuhuapi (AGOR "Vidal Gormaz”, 2001), y 5, frente a la Isla Toto (AGOR "Vidal Gormaz”, 2001).

\section{Material and methods}

Ophthalmolycus macrops, two specimens, IZUA-PM2298, 142 and $152 \mathrm{~mm}$ TL, Toto Island (44' 17,7'S; $\left.73^{\circ} 12,68^{\prime} \mathrm{W}\right), 250 \mathrm{~m}$ depth, 20 July 2001, two specimens IZUA-PM-2299, 118 and $136 \mathrm{~mm}$ TL,

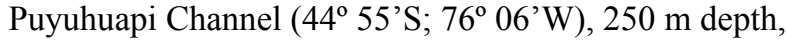
19 July 2001. The four aforementioned specimens were caught in a trawl set from the R/V "Vidal Gormaz", during the CIMAR 7-Fjords cruise. A fifth specimen, IZUA-PM-1912, $157 \mathrm{~mm}$ TL, was caught south of the
Magellan Straits at $\left(54^{\circ} 46,7^{\prime} \mathrm{S}, 7^{\circ} 08,6^{\prime} \mathrm{W}\right), 634 \mathrm{~m}$ depth, 21 November 1994, with an Agassiz net set by the B/C "Víctor Hensen", St. V.H. 1277, AGT 55 (Fig. 1). The methodology of Gosztonyi (1977), Anderson (1988), Anderson (1992), and Anderson \& Gosztonyi (1991) was used to take measurements and make counts related to various structures on the specimens.

Abbreviations used are: total length (TL), standard length (SL) and head length (HL). 


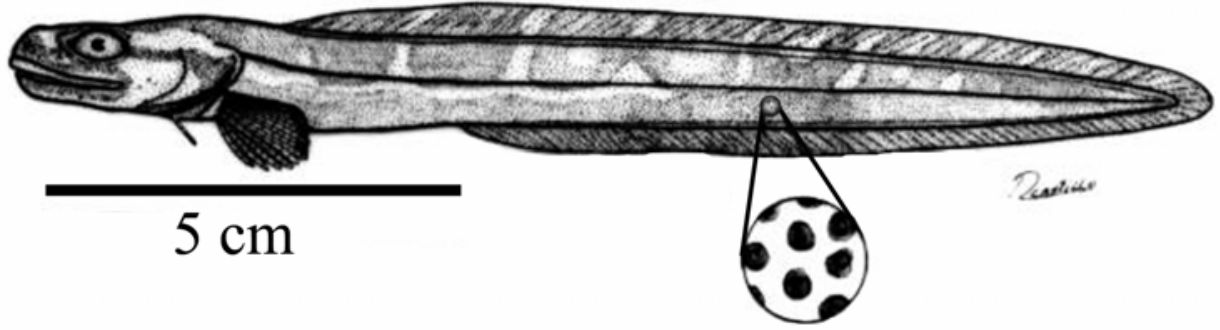

Figure 2

Ophthalmolycus macrops (Günther, 1880). Specimen $142 \mathrm{~mm}$ TL, IZUA-PM-2298. The circular projection shows form and disposition of scales in the zone indicated

Ophthalmolycus macrops (Günther 1880). Espécimen 142 mm LT, IZUA-PM 2298. La proyección circular muestra la forma y disposición de las escamas en la zona indicada

\section{Results}

The new O. macrops specimens, caught in the western channels of Aysén, agree well with previous descriptions (Fig. 2). There were, however, some features such as the length of the pectoral fin and the width of the head as percentages of the standard length which were in minor disagreement with data of other authors (Table 1). This also applied to the length of the upper jaw, ocular diameter, and interorbital distance (Table 2). Our observations also showed a consistent pattern of the cephalic pores: two nasal, six suborbital, eight preoperculo-mandibular, and two postorbitals (Fig. 3), which are within the ranges reported in previous literature (Günther 1880, Regan 1913, Norman 1937, Gosztonyi, 1977, Anderson, 1992, Anderson \& Gosztonyi 1991) (Table 3).

The depths of capture of these five new specimens ranged from 250 to $634 \mathrm{~m}$, with the latter depth the greatest one at which $O$. macrops was ever recovered. Two of the new captures north of the Magellan Straits represent new geographic records for the species, and that from Toto Island $\left(44^{\circ} 17,7^{\prime} \mathrm{S}\right)$, is the northernmost record documented to date. This site is about $600 \mathrm{~km}$ north of the type locality, Puerto Bueno. Recovery of this species south of the entrance of the Magellan Straits at $54^{\circ} 46,7^{\prime} \mathrm{S}$ extends its distribution to the south about $200 \mathrm{~km}$ at (approximately) the western entry to the straits (Fig. 1).

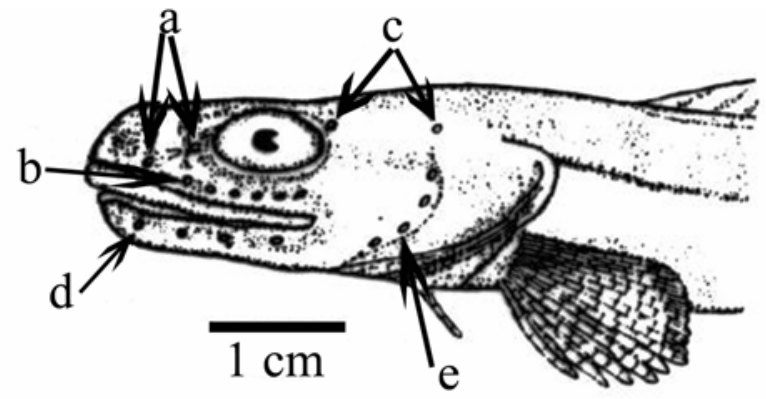

Figure 3

Head pore pattern in Ophthalmolycus macrops: a) Nasal, b) Suborbital, c) Postorbital, d) Mandibular, and e) Preopercular

Patrón de los poros cefálicos en Ophthalmolycus macrops: a) Nasal, b) Suborbital, c) Postorbital, d) Mandibular, y e) Preopercular

\section{Discussion}

Given the scarcity of records of Ophthalmolycus macrops in the scientific literature, it may be stated that it is a rare species. This might partly be due to its occurrence in areas which are rarely surveyed and partly because it may inhabit highly specific (and as yet unknown) niches, rarely subject to sampling. Based on previous data (Günther 1880, Regan 1913, Norman 
Table 1

Morphometric value ranges, in percentage of SL and TL of the specimens studied and their comparison with literature data Rangos de los valores morfométricos, en porcentajes de LS y LT de los especimenes estudiados y su comparación con la literatura

\begin{tabular}{|c|c|c|c|c|}
\hline & $\begin{array}{c}\text { Gosztonyi (1977) } \\
(\mathrm{N}=1) \\
(\% \mathrm{TL})\end{array}$ & $\begin{array}{c}\text { Anderson \& Gosztonyi } \\
\text { (1991) }(\mathrm{N}=7) \\
(\% \mathrm{SL})\end{array}$ & $\begin{array}{l}\text { Anderson (1992) } \\
\qquad \begin{array}{c}(\mathrm{N}=7) \\
(\% \mathrm{SL})\end{array}\end{array}$ & $\begin{array}{l}\text { Current study } \\
\qquad(\mathrm{N}=5) \\
(\% \mathrm{SL} / \mathrm{TL})\end{array}$ \\
\hline $\mathrm{SL} / \mathrm{TL}(\mathrm{mm})$ & 135 & $118-146$ & $118.5-146$ & $113-153 / 118-157$ \\
\hline Predorsal length & -- & $21-27$ & $21-27$ & 20.9-26.7/20.4-23.7 \\
\hline Preanal length & -- & $37-40$ & $37-40$ & $32.8-38.2 / 32.2-35.2$ \\
\hline Prepelvic length & 7.7 & -- & -- & $9.8-11.7 / 9.5-12.7$ \\
\hline Body depth & -- & $7-8$ & $7-8$ & $6.7-8.4 / 6.6-9.3$ \\
\hline Caudal fin length & -- & $3-4$ & $3-4$ & $35.3-26.1 / 33.9-25.4$ \\
\hline Pectoral fin length & -- & $8-9$ & $8-9$ & $4.4-10.7 / 4.2-9.9$ \\
\hline Pectoral fin height & -- & -- & -- & $4.1-4.6 / 3.9-7.0$ \\
\hline Head length & -- & $16-19$ & -- & $16.3-19.8 / 15.9-18.3$ \\
\hline Head width & -- & $7-9$ & -- & $5.2-8.4 / 5.1-7.7$ \\
\hline Head height & -- & -- & -- & $5.2-8.4 / 5.1-7.7$ \\
\hline Gill slitlength & -- & -- & -- & $6.7-7.9 / 6.6-7.6$ \\
\hline $\begin{array}{l}\text { Interpupillary } \\
\text { width }\end{array}$ & -- & -- & -- & $4.6-53 / 4.2-5.1$ \\
\hline
\end{tabular}

-- = not observed

Table 2

Morphometric value ranges, in percentage of HL of studied specimens and their comparison with literature data

Rangos de los valores morfométricos, en porcentajes de LC de los especimenes estudiados y su comparación con la literatura

\begin{tabular}{lcccc}
\hline & $\begin{array}{c}\text { Gosztonyi (1977) } \\
(\mathrm{N}=1)\end{array}$ & $\begin{array}{c}\text { Anderson \& Gosztonyi } \\
(1991)(\mathrm{N}=7)\end{array}$ & $\begin{array}{c}\text { Anderson (1992) } \\
(\mathrm{N}=7)\end{array}$ & $\begin{array}{c}\text { Current study } \\
(\mathrm{N}=5)\end{array}$ \\
\hline Head width & -- & $40-52$ & -- & $30.4-40$ \\
Head height & -- & -- & -- & $30.4-44$ \\
Pectoral fin length & -- & $48-59$ & $48-59$ & $23.8-60$ \\
Pelvic fin length & -- & -- & -- & $17.4-23.8$ \\
Caudal fin length & -- & -- & -- & $14.8-24$ \\
Upper jaw length & -- & $40-51$ & $40-51$ & $40.7-47.6$ \\
$\begin{array}{l}\text { Ocular diameter } \\
\text { Gill slit length }\end{array}$ & -- & $30-36$ & $30-36$ & $25.9-32$ \\
$\begin{array}{l}\text { Interorbital } \\
\text { distance }\end{array}$ & -- & $33-41$ & -- & $37-44$ \\
Interpupillary & 15.7 & $5-6$ & -- & $13-15.4$ \\
$\quad$ width & -- & $26-31$ & -- & $23.1-32$ \\
\hline$--=$ not observed & & & &
\end{tabular}


Table 3

\section{Meristic value ranges of the specimens studied and their comparison with literature data}

Rangos de los valores merísticos de los especimenes estudiados y su comparación con datos de la literatura

\begin{tabular}{|c|c|c|c|c|}
\hline & $\begin{array}{l}\text { Gosztonyi } \\
(1977) \\
(\mathrm{N}=1)\end{array}$ & $\begin{array}{l}\text { Anderson \& Gosztonyi } \\
\qquad \begin{array}{c}(1991) \\
(\mathrm{N}=7)\end{array}\end{array}$ & $\begin{array}{l}\text { Anderson (1992) } \\
\qquad(\mathrm{N}=7)\end{array}$ & $\begin{array}{l}\text { Current study } \\
\qquad(\mathrm{N}=5)\end{array}$ \\
\hline Dorsal fin rays & 95 & $91-95$ & $91-95$ & 90 \\
\hline Anal fin rays & 84 & $79-83$ & $79-83$ & $80-83$ \\
\hline Pectoral fin rays & 15 & $14-15$ & $14-15$ & $14-15 ?$ \\
\hline Pelvic fin rays & -- & 3 & 3 & 3 \\
\hline Caudal fin rays & -- & $9-10$ & $9-10$ & 10 \\
\hline Branchiostegal rays & -- & 5 & 5 & 5 \\
\hline Gillrakers 1st arch & 10 & $9-10$ & $10-11$ & 9 \\
\hline \multicolumn{5}{|l|}{ Pores: } \\
\hline Preoperculo-mandibular & 8 & 8 & 8 & 8 \\
\hline Suborbital & $6-7$ & 6 & 6 & 6 \\
\hline Nasal & -- & 2 & 2 & 2 \\
\hline Postorbital & 2 & 2 & 2 & 2 \\
\hline Interorbital/occipital & -- & 0 & 0 & 0 \\
\hline
\end{tabular}

1937, Gosztonyi, 1977, Anderson \& Gosztonyi 1991, Anderson 1992), only seven specimens have been available for study until the present one. Thus, the five specimens forming the basis of the present report form an important contribution to the knowledge of this rare species, representing almost half of all known specimens in the world.

Apart from the differences in some characteristics, the specimens of the present study agree well with previous descriptions (Günther 1880, Regan 1913, Norman 1937, Gosztonyi 1977, Anderson \& Gosztonyi 1991, Anderson 1992), and the differences are considered as due to intraspecific variation. Our specimens were in excellent condition, leading to the assumption that the differences observed from previous results were not due to preservation method or other causes.

The new limits of distribution herein presented suggest that $O$. macrops is endemic to Chile's southern channels, at depths corresponding to a deep continental shelf, or to the upper continental slope. Based on the new records herein reported, the distribution of $O$. macrops does not appear to have obstacles which could be considered major geographic barriers, such as the Taitao peninsula. In fact, this species until now considered as endemic to the Patagonian fjords, lives both north and south of this peninsula. It is probable that Taitao peninsula can acts as a barrier for shallow water fishes such as those of the intertidal and upper subtidal zones (generally $\leq 40-50 \mathrm{~m}$ ), but would not be a barrier to fishes from deeper habitats such as $O$. macrops.

The geographic distribution now known for $O$. macrops shows that this species lives in depths typical of the deep continental shelf and upper slope, and thus should not be compared with other intertidal or subtidal fish species of different families, because of its possible different evolutionary origin and different environmental conditions.

This species was previously recovered from depths of 73 to $552 \mathrm{~m}$ (Anderson \& Gosztonyi 1991, Anderson 1992), now extended to $634 \mathrm{~m}$. Analyses of the catches of $O$. macrops have also permitted a historical vision of the few known records (Fig. 1). The results of the present study also mean important contribution for a broad understanding of the South American zoarcids 
and further studies on it, because include new morphological data and offers new biological material as documented evidences preserved in appropriate scientific collections.

\section{Acknowledgments}

We thank personnel from the R/V "Vidal Gormaz", for their assistance in obtaining samples during CIMAR 7Fjord Cruise; M. E. Anderson (South African Institute for Aquatic Biodiversity, Grahamstown, South Africa) and A. E. Gosztonyi (Centro Nacional Patagónico, Puerto Madryn, Argentina), who provided valuable bibliography. Dr. Anderson was of great help, as he confirmed the identification of O. macrops and making valuable comments on the manuscript. The Deutsche Akademische Austaudienst (D.A.A.D.) financed a trip for the first author to Bremerhaven, in order to study ichthyological materials obtained by the cruise of the R/V "Victor Hensen" in 1994. Dr. Wolf Arntz, Director, Alfred Wegener Institut, Bremerhaven, Germany, lent valuable help from his Institute. Luis Hidalgo (Librarian, Museo Nacional de Historia Natural, Santiago) aided by obtaining bibliographic materials; León Matamala (Instituto de Zoología, Universidad Austral de Chile) provided laboratory assistance. We also acknowledge the judgements and opinions of two anonymous referees, which helped to improve this contribution. This report represents partial results from CIMAR-7 Fiordos Project, of the Comité Oceanográfico Nacional (CONA) and Project DID2005-03 of the Universidad Austral de Chile.

\section{Literature cited}

Anderson ME. 1988. Studies on the Zoarcidae (Teleostei: Perciformes) of the southern hemisphere. I. The Antarctic and Subantarctic regions. Biology of the Antarctic Seas XIX Antarctic Research Series 47: 59-113.

Anderson ME. 1992. Studies on the Zoarcidae (Teleostei: Perciformes) of the southern hemisphere. VI. Review of the genus Ophthalmolycus Regan, 1913, with description of a new species from Chile. JLB Smith Institute of Ichthyology, Special Publication 53: 1-10.

Anderson ME \& AE Gosztonyi. 1991. Studies on the Zoarcidae (Teleostei: Perciformes) of the Southern Hemisphere. IV. New records and a new species from the Magellan Province of South America. JLB Smith Institute of Ichthyology, Ichthyological Bulletin 55: 1-16.

Gosztonyi AE. 1977. Results of the research cruises of FRV "Walther Herwig" to South America. XLVIII, Revision of the South American Zoarcidae (Osteichthyes: Blennioidei), with the description of three new genera and five new species. Archiv für Fischereiwissenschaft 27(3): 191-249.

Günther A. 1880. Report on the shore fishes procured during the voyage of H.M.S. "Challenger" in the years 18731876. Reports Scientific Research Challenger 1(6): 1-82.

Norman JR. 1937. Coast Fishes, Part 2, The Patagonian Region. Discovery Reports 16: 1-150 .

Pequeño G \& J Lamilla. 1996. Preliminary report on the demersal fish material collected during the "Victor Hensen" Magellan Campaign. Berichte zur Polarforschung 190: 68-70; 105-106.

Regan CT. 1913. The Antarctic fishes of the Scottish National Antarctic Expedition. Transactions of the Royal Society of Edinburgh 49(15): 229-292. 